\title{
Scriptaid overcomes hypoxia-induced cisplatin resistance in both wild-type and mutant p53 lung cancer cells
}

\author{
Shrikant Pradhan ${ }^{1}$, Divyank Mahajan, Prabhjot Kaur ${ }^{1}$, Namita Pandey ${ }^{1}$, Chandresh \\ Sharma ${ }^{2}$, Tapasya Srivastava ${ }^{1}$ \\ ${ }^{1}$ Department of Genetics, University of Delhi South Campus, New Delhi, India \\ ${ }^{2}$ Centre for Bio-design and Diagnostics, Translational Health Science and Technology Institute, Faridabad, Haryana, India
}

Correspondence to: Tapasya Srivastava, email: tapasya@south.du.ac.in

Keywords: lung cancer, cisplatin, scriptaid, hypoxia, metastasis

Received: January 08, 2016

Accepted: September 25, 2016

Published: September 30, 2016

\section{ABSTRACT}

Non-small cell lung cancer (NSCLC), comprising $85 \%$ of lung cancer cases, has been associated with resistance to chemo/radiotherapy. The hypoxic tumor microenvironment, where insufficient vasculature results in poor drug penetrance and suboptimal chemotherapy in the tumor interiors contributes heavily to this resistance. Additionally, epigenetic changes in tumorigenic cells also change their response to different forms of therapy. In our study, we have investigated the effectiveness of a combination of cisplatin with scriptaid [a pan-Histone Deacetylase inhibitor (HDACi)] in a model that mimics the tumor microenvironment of hypoxia and sublethal chemotherapy. Scriptaid synergistically increases the efficacy of cisplatin in normoxia as well as hypoxia, accompanied with reduced metastasis and enhanced DNA damage. Addition of scriptaid also overcomes the cisplatin resistance exhibited in lung cancer cells with stabilized hypoxia inducible factor 1 (HIF1)-a (mutant) and mutant p53. Molecular studies showed that the combination treatment increased apoptotic cell death in both normoxia and hypoxia with a dual role of p38MAPK. Together, our results suggest that the combination of low dose cisplatin and scriptaid is cytotoxic to NSCLC lines, can overcome hypoxia induced resistance and mutant p53- induced instability often associated with this cancer, and has the potential to be an effective therapeutic modality.

\section{INTRODUCTION}

Lung cancer is a malignancy of the respiratory epithelium and the leading cause of cancer related deaths worldwide. Of the two types of lung cancer, small cell lung cancer (SCLC) and non-small cell lung cancer (NSCLC), the latter comprises about $85 \%$ of the total cases [1]. Among the different genetic abnormalities associated with lung cancer, mutations in $p 53, K R A S, E G F R$ and $L K B 1$ are the most common. Mutations in p53 gene occur early in cancer development and are maintained throughout the advanced stages of tumor development [2, 3]. With an overall survival rate of five years, the treatment outcome of NSCLC still remains poor. However, the management of locally advanced NSCLC has progressed significantly with the use of combined therapeutic interventions [4].
Standard treatment for advanced stages of NSCLC is surgery followed by platinated drug-based adjuvant therapy. Although cisplatin is a drug of choice for NSCLC treatment $[5,6]$, patients are known to acquire drug resistance.

Overcoming cisplatin-resistance, therefore, is a crucial factor for developing anticancer therapy [7]. The hypoxic tumor micro-environment is one of the key players in acquired chemo/radio resistance mainly due to poor penetrance. The resulting low doses in tumor interiors leads to metabolic and genetic changes in a hypoxic cell favoring cell proliferation, angiogenesis and metastasis [8]. We have shown previously, that low dose cisplatin induces genomic instability in hypoxic glioma cells [9]. Hypoxia inducible factor $1 \alpha(H I F 1 \alpha)$, identified by Wang and Semenza, is the oxygen sensor which activates a host of hypoxia inducible 
genes [10]. Deletion of HIFl $\alpha$ in a mouse mammary tumor virus (MMTV) promoter-driven polyoma middle $T$ antigen mouse model of breast cancer showed reduction in growth of the primary tumors [11]. In contrast, HIFl $\alpha$ deletion in a KRAS-driven mouse model of lung cancer had negligible effect on tumor burden and progression, whereas a deletion in its isoform, $H I F 2 \alpha$ increased tumor growth and progression [12]. In renal cell carcinoma, stabilization of HIF $1 \alpha$ reduced tumor progression, while overexpression of $H I F 2 \alpha$ resulted in increased tumorigenesis $[13,14]$. Thus, the role of HIF isoforms is complex and differs with tumor and stromal cell types.

Overcoming this chemo-resistance with the help of specific inhibitors and modulators has had moderate success. For example, initial trials of tirapazamine (TPZ) in combination with chemo/radiotherapy showed promising results in NSCLC, cervical and head and neck cancers [15-18] however, subsequent phase III trials failed to demonstrate its effectiveness $[19,20]$.

Alterations in epigenetic marks- histone acetylation and methylation of gene promoters- are also known to contribute to the onset and progression of various types of cancers [21]. Hypoxia has been shown to induce epigenetic changes in the cancer genome by us [22] and others [23-25]. In hypoxic conditions, histone deacetylases interact with HIF $1 \alpha$ to regulate the expression of many genes. While interaction of HIF $1 \alpha$ with HDAC1 downregulates HIF-targets such as RECK and Reptin [26, 27], recruitment of HDAC4, HDAC5 and HDAC7 increases the expression of HIF $1 \alpha$-regulated genes [28].

We have investigated the ability of scriptaid, a pan HDAC inhibitor (HDACi) in sensitizing lung cancer cells to low dose cisplatin. A low dose cisplatin is reflective of what the hypoxic interiors of lung cancer are likely to receive and what a patient needs, to minimize side-effects. Considering the well-established role of hypoxia and HIF1 in regulating key cellular and molecular pathways in cancer progression, it seems relevant to investigate therapeutic molecules and regimes in in vitro hypoxic conditions. We have determined whether this combination treatment can overcome cisplatin-resistance in hypoxia and have investigated the underlying mechanism of cell death. We have also studied the effectiveness of this combination therapy in the p53 dominant negative lung cancer cells, hence addressing the prevalence of a significant percent of NSCLC. Lastly, we have studied combination therapy in mutant HIF $1 \alpha$ overexpressing genetic background to address the molecular mechanism in more detail.

\section{RESULTS}

\section{Cisplatin and scriptaid induce dose dependent cytotoxicity in lung cancer cells}

Lung cancer cell lines, A549 and H460 showed dose dependent cell cytotoxicity with both cisplatin (Figure 1A) and scriptaid (Figure 1B) in normoxia. The IC50 concentration of cisplatin for A549and H460 was $4.3 \mu \mathrm{g} / \mathrm{ml}$ and $3.5 \mu \mathrm{g} / \mathrm{ml}$, respectively. The IC50 concentration of scriptaid for A549 and $\mathrm{H} 460$ was determined at $2.8 \mu \mathrm{g} / \mathrm{ml}$ and $2 \mu \mathrm{g} / \mathrm{ml}$, respectively. To confirm the activity of scriptaid, A549 cells were treated with three different concentrations for $24 \mathrm{hrs}$ and western blot analysis performed for the acetylated histone $\mathrm{H} 4$. A concentration-dependent increase in the expression of acetylated histone $\mathrm{H} 4$ was observed in response to scriptaid (Supplementary Figure S1A).

\section{Lung cancer cells showed cisplatin resistance in hypoxia}

Solid tumors are known to harbor heterogeneous hypoxic regions in the interiors. We have assessed cytotoxicity to cisplatin treatment in cells cultured in two grades of hypoxia- $1 \% \mathrm{O} 2(1 \%$ hypoxia) and $0.2 \%$ $\mathrm{O} 2(0.2 \%$ hypoxia). As expected, they showed variable response to cytotoxicity. In $1 \%$ hypoxia, A549 cells showed significant resistance to cisplatin compared to that in normoxia for all four doses. But in near-anoxic condition of $0.2 \%$ hypoxia, A549 cells exhibited resistance only at higher doses (Figure 1C). On the contrary, H460 cells showed resistance to all doses of cisplatin in $0.2 \%$ hypoxia whereas in conditions of $1 \%$ hypoxia the cells showed resistance at higher doses of cisplatin but not in lower and median doses (Figure 1D). Induction and stabilization of HIF $1 \alpha$, was confirmed by western blotting in A549 cells at both doses of hypoxia (Figure S2A). Overexpression of HIF $1 \alpha$-inducible genes- GLUT1 and $C A I X$ validated the conditions of in vitro hypoxia (Figure S2B). Cell cycle analysis using flow cytometry showed a G2-M and S-phase arrest at lower doses of cisplatin and a dose-dependent increase in cell death in normoxic condition. However, in hypoxic conditions, cell cycle arrest was averted and the amount of cell death was relatively lower. The G0-G1 population was significantly higher in hypoxic conditions than that observed in normoxia (Supplementary Figure S2C).

\section{Scriptaid acts synergistically with cisplatin and overcomes hypoxia-induced cisplatin resistance}

One low dose of cisplatin $(2 \mu \mathrm{g} / \mathrm{ml})$ and two doses of scriptaid $(1 \mu \mathrm{g} / \mathrm{ml}$ and $2 \mu \mathrm{g} / \mathrm{ml})$ were selected for studying cytotoxicity with combination therapy in A549 and H460 cells. Sequential addition of drugsscriptaid treatment for 2-4 hrs followed by cisplatin treatment- did not result in elevated cytotoxicity (data not shown). Simultaneous addition of both the drugs showed promising results. The combinations used- $2 \mu \mathrm{g} / \mathrm{ml}$ cisplatin $+1 \mu \mathrm{g} / \mathrm{ml}$ scriptaid and $2 \mu \mathrm{g} / \mathrm{ml}$ cisplatin $+2 \mu \mathrm{g} / \mathrm{ml}$ scriptaid-synergistically improved the efficacy of low dose cisplatin in normoxic conditions $(p<0.005)$ in A549 (Figure 2A). Synergism was calculated as described by 
Kern et al. (1998), where, an $\mathrm{R}$ index of $>1.5$ signifies synergism. Further, the combination proved to be effective in overcoming cisplatin resistance in both conditions of hypoxia- $1 \%$ and $0.2(p<0.005)$. The $\mathrm{R}$ index of both combinations were $>1.5$ in $1 \%$ hypoxia and $0.2 \%$ hypoxia (Figure 2A). DAPI staining of A549 cells showed an overall higher number of apoptotic population in combination treated samples compared to that observed in mono therapy (Supplementary Figure S1B). It was observed that scriptaid did not influence the expression of HIF $1 \alpha$ under hypoxia (Supplementary Figure S4A). Although single agent cisplatin and scriptaid were less effective in hypoxic conditions, the combination treatment leads to an increase in apoptosis in these cells. Poly-ADP ribose polymerase
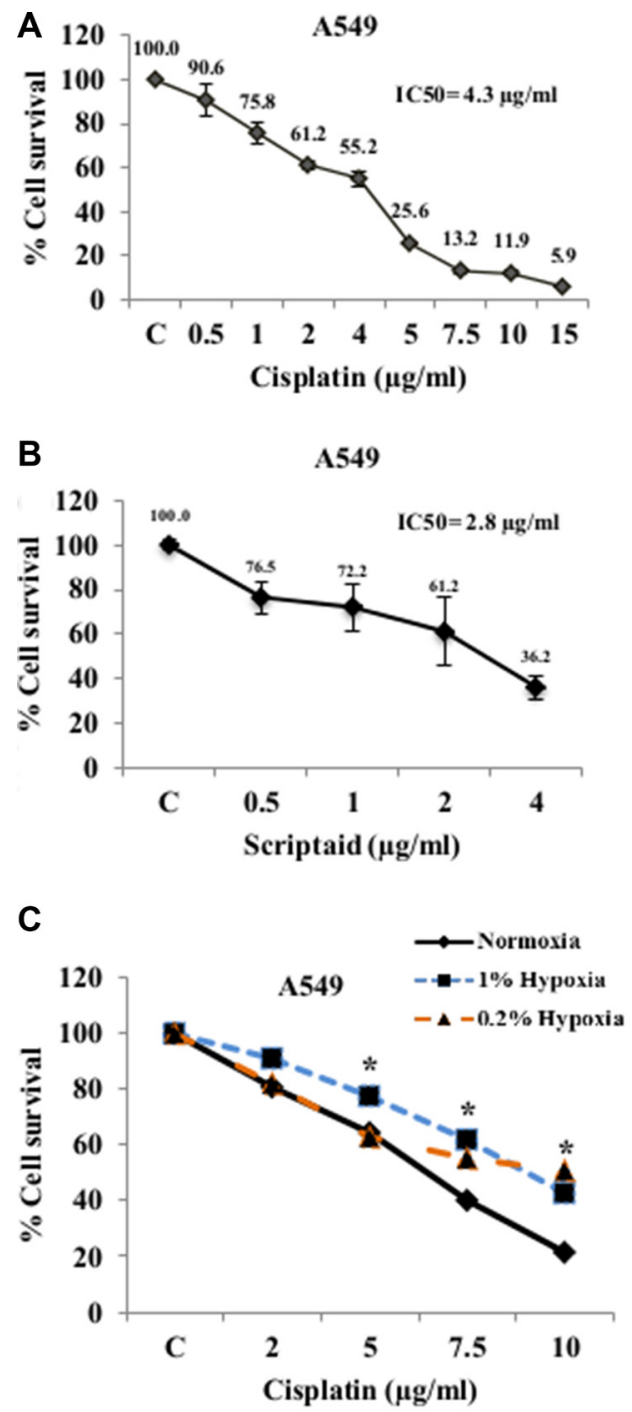

(PARP) expression further supports cytotoxicity data, where the combination therapy synergistically improves the toxicity of low dose cisplatin in all three conditionsnormoxia, $1 \%$ hypoxia and $0.2 \%$ hypoxia (Figure $2 \mathrm{~B}$ ). The combination treatment was also effective in $\mathrm{H} 460$ cells in both normoxic and hypoxic conditions (Figure 2C).

\section{Combination therapy inhibits migratory behavior of A549 cells}

For further analysis, a combination of $2 \mu \mathrm{g} / \mathrm{ml}$ cisplatin $+1 \mu \mathrm{g} / \mathrm{ml}$ scriptaid was used for all in vitro studies. Clonogenic assay showed that the combination treatment resulted in significantly fewer colonies compared to
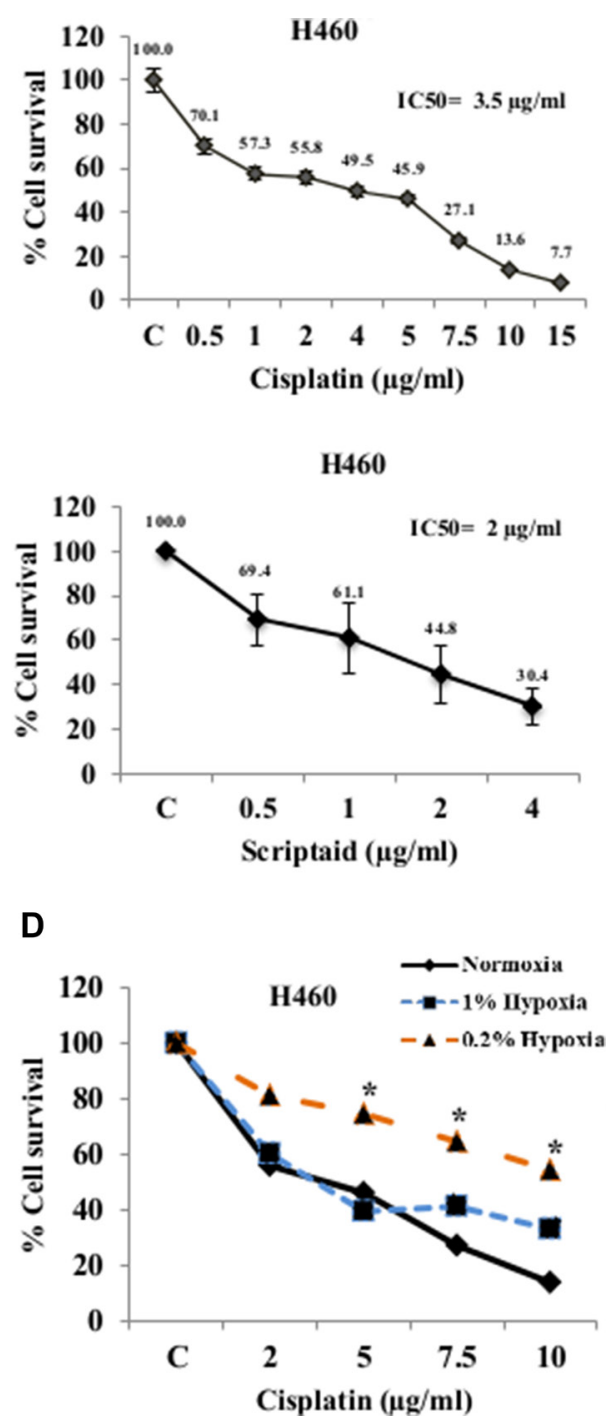

Figure 1: Cytotoxicity assay for Cisplatin and Scriptaid on lung cancer cells. MTT assay of A549 and H460 cells for cytotoxicity to cisplatin (A) and scriptaid (B). The IC50 values of A549 and H460 cells for cisplatin was 4.3 and $3.5 \mu \mathrm{g} / \mathrm{ml}$ and that for scriptaid was 2.8 and $2 \mu \mathrm{g} / \mathrm{ml}$ respectively. MTT assay for cisplatin in A549 (C) and H460 (D) cells showing resistance to the drug in hypoxic conditions ( $1 \%$ and $0.2 \%$ ) compared to that in normoxia. $\mathrm{C}=$ untreated control. $*$ indicates $p<0.05$. 


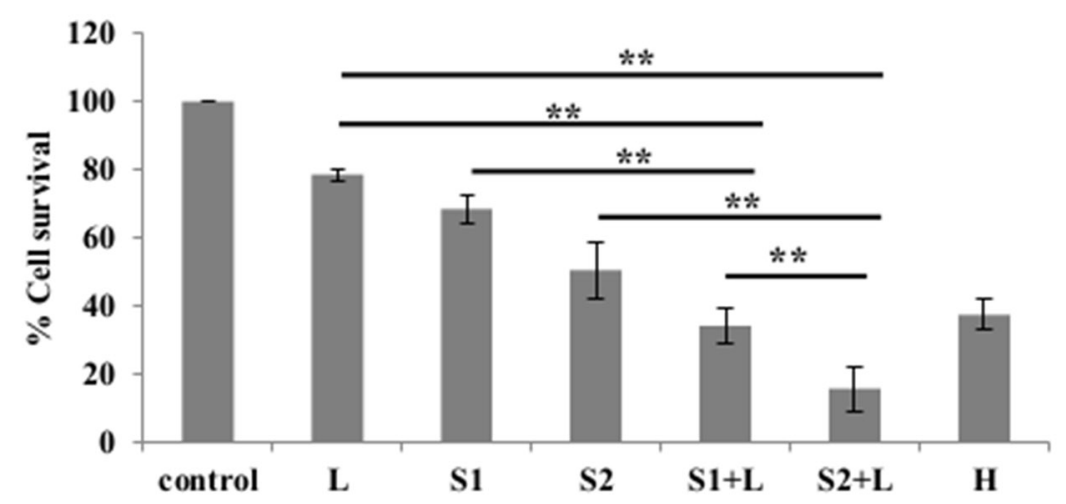

A549- 1\% Hypoxia

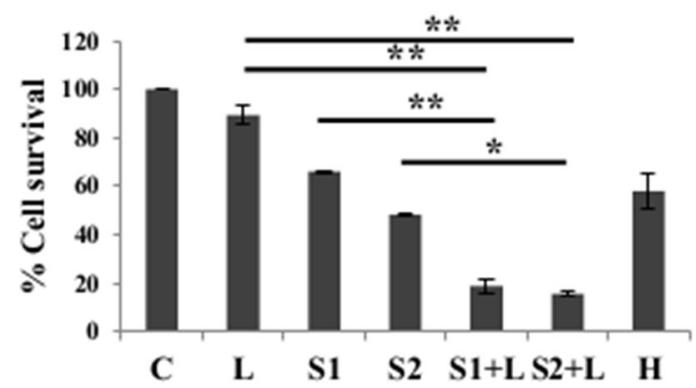

B

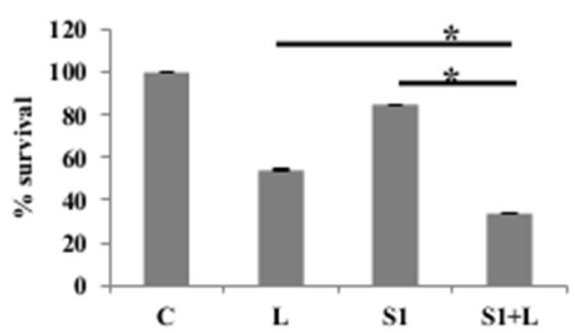

A549- 0.2\% Hypoxia

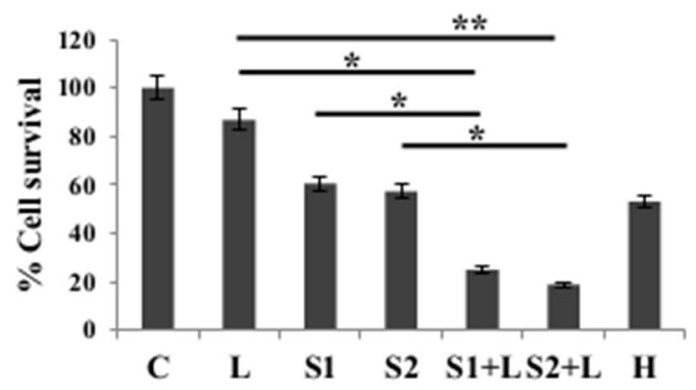

H460-1\% Hypoxia

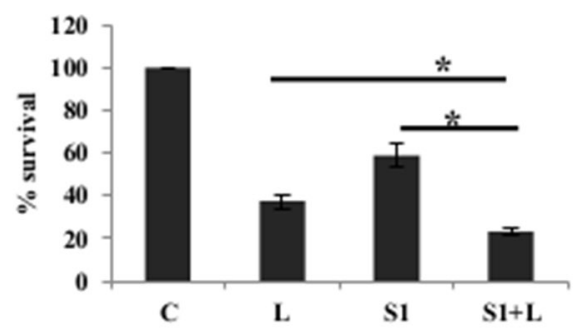

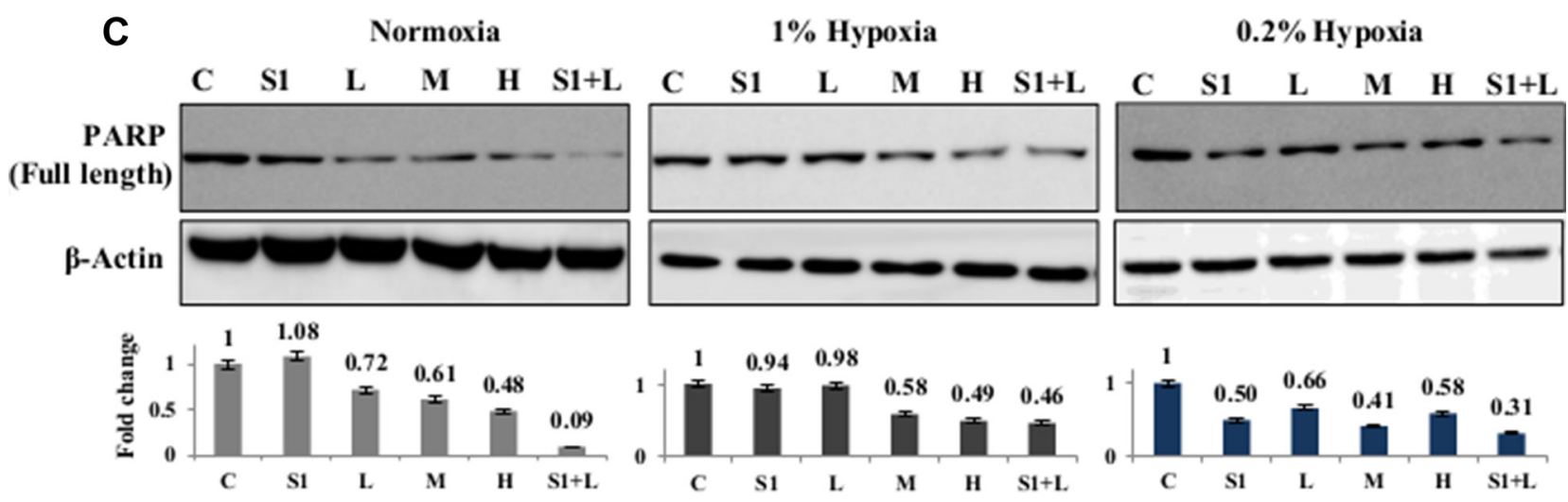

Figure 2: Synergistic effect of combination treatment. (A) Combination of cisplatin and scriptaid at sub-lethal doses showing significantly enhanced cytotoxicity than either of single agent treatment and high dose cisplatin. The combination remained effective in both condition of hypoxia- $1 \%$ and $0.2 \%$. (B) MTT assay of $\mathrm{H} 460$ cells shows that the combination treatment was significantly more effective than either of the single agent in both normoxic and hypoxic conditions. (C) Cleavage of PARP as seen by western blot analysis as a marker for cell death. High dose cisplatin and combination treatments resulted in greater amount of cell death in all conditions. Graphs represent the fold change in expression of cleaved PARP, normalized with the loading control- $\beta$-actin. $\mathrm{C}=$ untreated control, $\mathrm{L}=2 \mu \mathrm{g} / \mathrm{ml}$ cisplatin, $\mathrm{M}=$ $5 \mu \mathrm{g} / \mathrm{ml}$ cisplatin $\mathrm{H}=7.5 \mu \mathrm{g} / \mathrm{ml}$ cisplatin, $\mathrm{S} 1=1 \mu \mathrm{g} / \mathrm{ml}$ scriptaid, $\mathrm{S} 2=2 \mu \mathrm{g} / \mathrm{ml}$ scriptaid. * indicates $p<0.05$, ** indicates $p<0.005$. 
cisplatin and scriptaid monotherapy $(p<0.05)$ (Figure 3A) and inhibited wound healing in both normoxia and hypoxia (Supplementary Figure S3). In hypoxic conditions, single agent treatment did not inhibit cell migration to the same extent as that in normoxia. However, the doublet treatment significantly inhibits cell migration in both conditions (Figure 3B). Enhanced migratory behavior of lung cancer cells in hypoxic conditions can be attributed to the overexpression of mesenchymal markers viz. $M M P-2,3,9$,
$C D H 2$ and $S N A I 2$, together with the down-regulation of $\mathrm{CDH1}$ - an epithelial marker (Figure 3C). Further analysis of the EMT markers in response to treatment shows that the combination treatment down-regulated the expression of matrix metalloproteases (MMPs). The epithelial marker, $C D H 1$, was up-regulated in response to combination treatment in hypoxia (Figure 3D). Thus, the combination treatment inhibits cell migration by repressing mesenchymal genes.

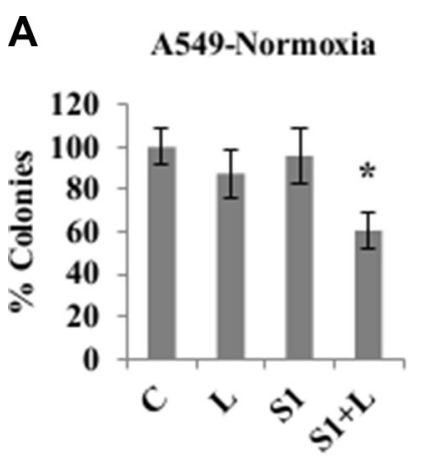

B

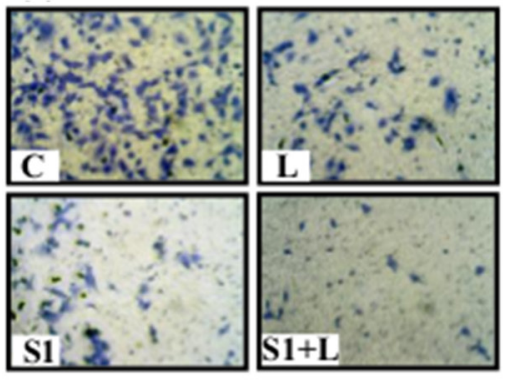

C
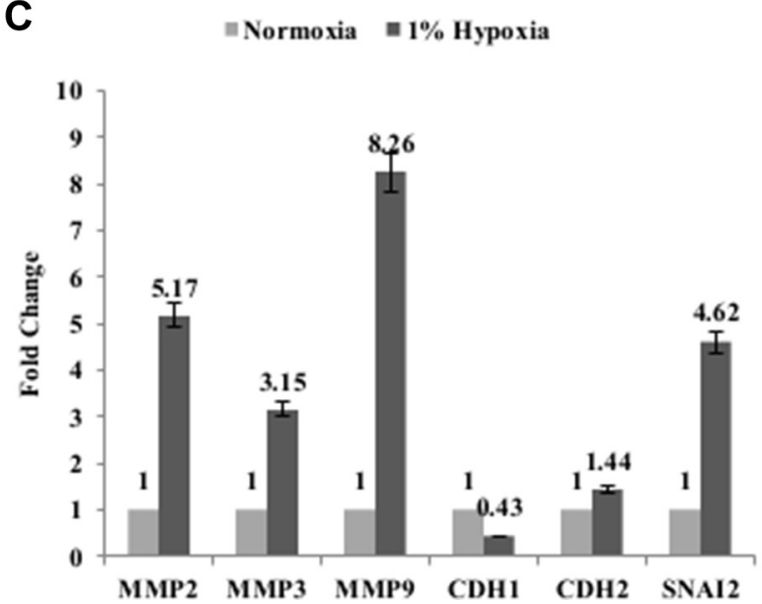

A549-1\% Hypoxia

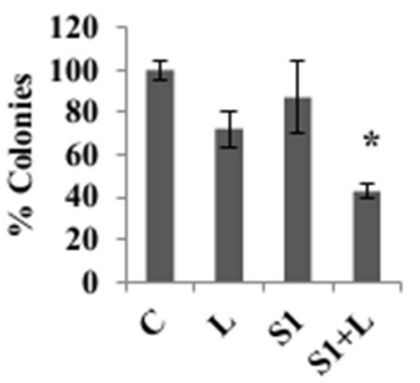

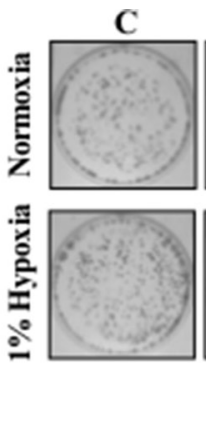

$\mathbf{L}$

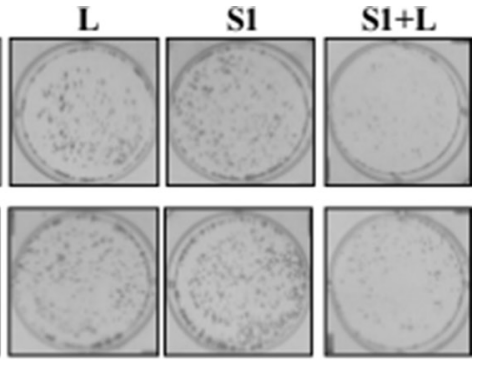

$\mathbf{S} 1+\mathbf{L}$
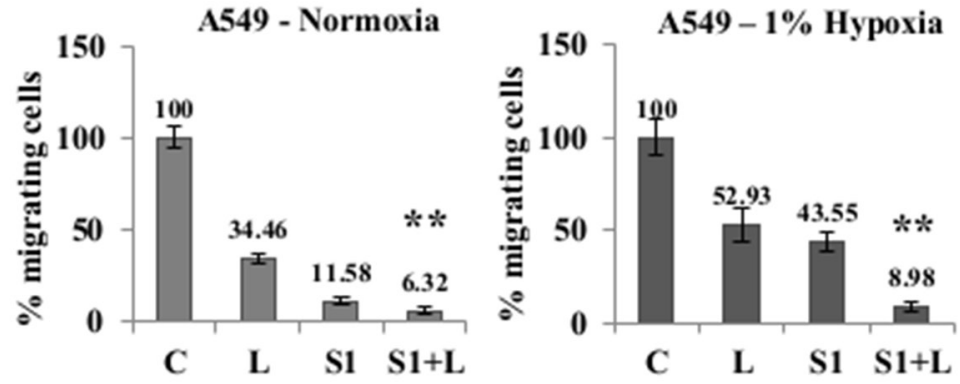

D
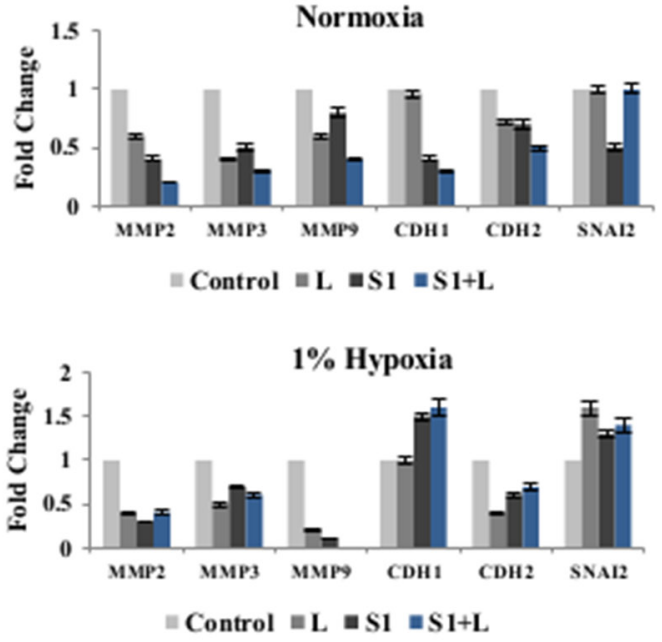

Figure 3: Combination treatment impairs clonogenic and migratory potential of cancer cells. (A) Clonogenic assay shows a significant inhibition of colony formation in doublet treated samples compared to single agent cisplatin and scriptaid in normoxia as well as 1\% hypoxia. (B) Representative picture of migration assay in normoxia; Migration assay using Boyden chambers shows a significant inhibition of cell migration in combination treatment compared to single agent treatment in both normoxic and hypoxic conditions. (C) Real-time PCR analysis of EMT markers showed an up-regulation of mesenchymal markers and down-regulation of epithelial marker under hypoxic condition when normalized against normoxia. (D) Real-time PCR of EMT markers in response to mono and combination treatment in normoxic and hypoxic conditions shows down-regulation of mesenchymal markers and up-regulation of epithelial marker in hypoxic condition. $\mathrm{C}=$ control, $\mathrm{L}=2 \mu \mathrm{g} / \mathrm{ml}$ cisplatin, $\mathrm{S} 1=1 \mu \mathrm{g} / \mathrm{ml}$ scriptaid. $\mathrm{MMP}=$ matrix metalloprotinase; $\mathrm{CDH} 1=\mathrm{cadherin} 1 / \mathrm{E}-\mathrm{cadherin}$; $\mathrm{CDH} 2=$ cadherin $1 / \mathrm{N}$-cadherin; SNAI2 $=$ Snail2. $*$ indicates $p<0.05, * *$ indicates $p<0.005$. 


\section{Combination therapy leads to apoptotic cell death in A549 cells}

The combination therapy induced apoptotic cell death in both normoxic and hypoxic conditions as determined by AnnexinV labeling (Figure 4A). Single agent cisplatin and scriptaid did not induce apoptosis. However, majority of the cell population in combination treated samples were in early and late phase apoptosis. In combination treated samples of both normoxia and hypoxia, enhanced expression of p53 and $\gamma$-H2AX was observed (Figure 4B). Cleavage of caspase-3 and caspase- 8 indicates that the combination treatment activates the extrinsic pathway of apoptotic cell death (Figure 4C). NFKB expression remained unaffected by mono and combination treatment in both conditions. The expression of phosphorylated-p38MAPK (p-p38MAPK) was differentially regulated compared to total p38MAPK. The increased accumulation of p-p38MAPK in treated samples indicates its role in apoptosis in normoxic condition while, the over-expressed p-p38MAPK in untreated hypoxic conditions is significantly reduced in treated samples (Figure 4C).

\section{Scriptaid sensitizes cisplatin-resistant HIF1a- stable mutant cells to apoptotic cell death}

One of the key players in regulating hypoxia-induced cisplatin-resistance is the HIF $1 \alpha$. We generated a HIF $1 \alpha$ overexpressing stable mutant (HA-HIF1alpha P402A/ P564A-pcDNA3 vector) cell line to study the contribution of HIF $1 \alpha$ to our results on hypoxia. Stably transfected A549 cells showed elevated HIF $1 \alpha$ expression even under normal oxygen concentration (Figure 5A). Up-regulation of GLUT1 (about 8 folds) and CAIX (about 6 folds), the two HIF $1 \alpha$ inducible genes, in A549-HIF1 $\alpha$ mut cell line compared to the vector control cell line (Figure 5B) confirmed the effectiveness of HIF $1 \alpha$ overexpression. The mutant cell line also had a proliferative advantage over the vector control A549 cells (Figure 5C). They showed resistance to cisplatin induced cytotoxicity compared to A549 cells with wt-HIF $1 \alpha$ (Figure 5D) similar to our results in hypoxia. The combination treatment also significantly reduced cell migration $(p<0.05)$ in the mutant cell line compared to single agent treatment (Figure 5E). Immunofluorescence staining using $\gamma-\mathrm{H} 2 \mathrm{AX}$ antibody showed that the mutant cell line was more resistant to single agent cisplatin and scriptaid than the wild type counterpart, while the combination therapy resulted in an increased amount of DNA damage (Figure 6A). The corrected total fluorescence (CTCF) was significantly higher in combination treatment than single agent treatment (Supplementary Figure S4B). Lastly, annexinV/PI dual staining and flow cytometry analysis shows the enhanced cytotoxicity via apoptosis of combination treatment in a HIF $1 \alpha$ over-expressing mutant background (Figure 6B) similar to that in physiological hypoxia.

\section{Cisplatin resistant A549/p53DN cells undergo apoptotic cell death in presence of scriptaid}

Mutations in p53 are common in cancer, with $\mathrm{R} 175 \mathrm{H}$ position mutation being the most common. We have generated a stable p53-R175H-dominant negative (DN) mutant in A549 cell line to answer two questions(a) whether this mutation affects the sensitivity of cancer cells to cisplatin and (b) can scriptaid improve the efficacy of cisplatin in such a mutant background. The pCMVNeo-BamR175H vector codes for a mutant p53 gene which dimerizes with cellular wt-p53 and renders it nonfunctional. The stable mutant cell line was generated and confirmed by western blot analysis using p53-specific monoclonal antibody (Figure 7A). Cytotoxicity assays for cisplatin showed that the mutant cell line was significantly resistant to all doses of cisplatin compared to the wildtype control (Figure 7B). MTT assay of A549-R175H in both normoxic and hypoxic conditions shows a synergistic effect of combination treatment (Figure S4C). In normoxic condition, A549-R175H cells were less sensitive to single agent cisplatin and scriptaid, while the combination therapy lead to an increased accumulation of $\gamma-\mathrm{H} 2 \mathrm{AX}$ indicating greater amount of DNA damage in these samples (Figure 7C). Protein expression of PARP, caspase- 3 and caspase- 8 shows that the combination treatment leads to apoptotic cell death in A549-R175H cells whereas single agent treatment proved ineffective (Figure 7D). Further proof of apoptotic cell death was provided by annexinV/PI staining and flow cytometry analysis (Figure 7E). The combination therapy led to significantly greater amount of cell death compared to monotherapy with either cisplatin or scriptaid. Thus, combination therapy with low dose cisplatin and scriptaid can also overcome cisplatin-resistance which results from a dominant-negative mutation of p53 in lung cancer cells. Molecular analysis of apoptosis markers in hypoxia shows an activation of caspase- 8 , while caspase-3 was not significantly affected by the combination treatment (Supplementary Figure S4C).

\section{DISCUSSION}

The hypoxic tumor microenvironment is a fertile bed for chemo-resistance, genetic alterations and changes in cellular phenotype. Low drug perfusion in hypoxic interior of tumors changes the cytotoxicity and the associated signaling networks. Cisplatin is a commonly used drug for the treatment of non-small cell lung cancer and patients often develop resistance to cisplatin over the course of therapy and multiple mechanisms have been attributed to the resistance, including hypoxia [31, 32]. On-going research efforts aim to overcome this chemoresistance, however, the outcomes have been limited. In our study we have addressed this hurdle of hypoxiainduced cisplatin resistance in non-small cell lung cancer 
A

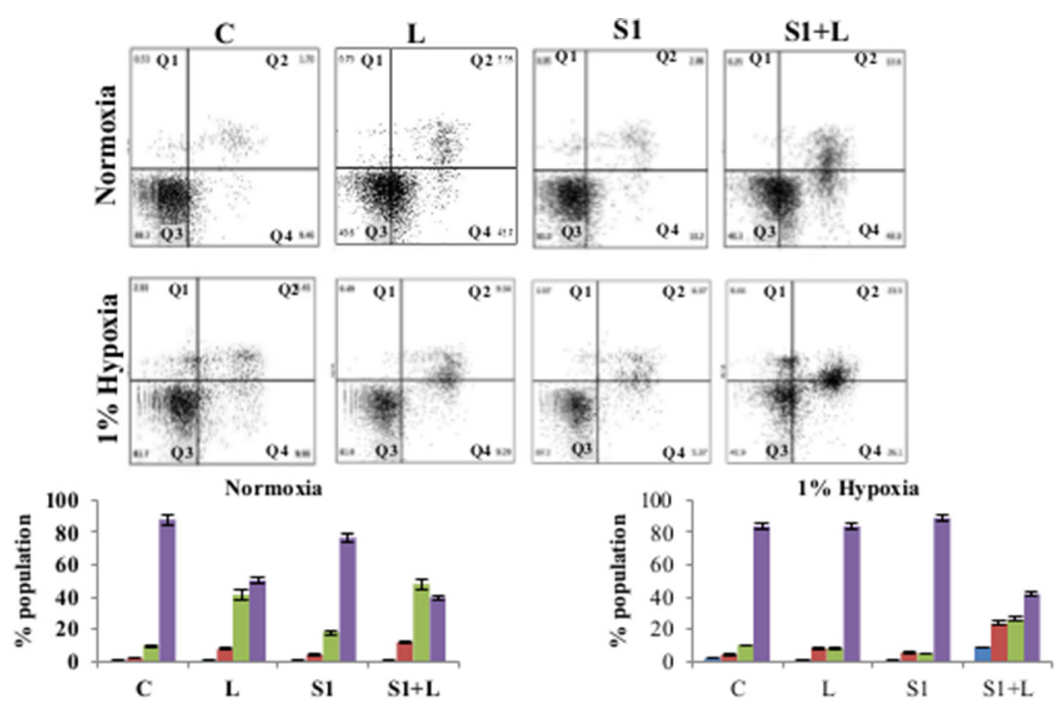

- PI $=$ PI+AnnexinV $=$ AnnexinV $=$ Live

$\equiv \mathrm{PI} \equiv \mathrm{PI}+\mathrm{Annexin} \mathrm{V} \equiv$ Annexin $\mathrm{E}$ Live

B

Normoxia

$1 \%$ Hypoxia
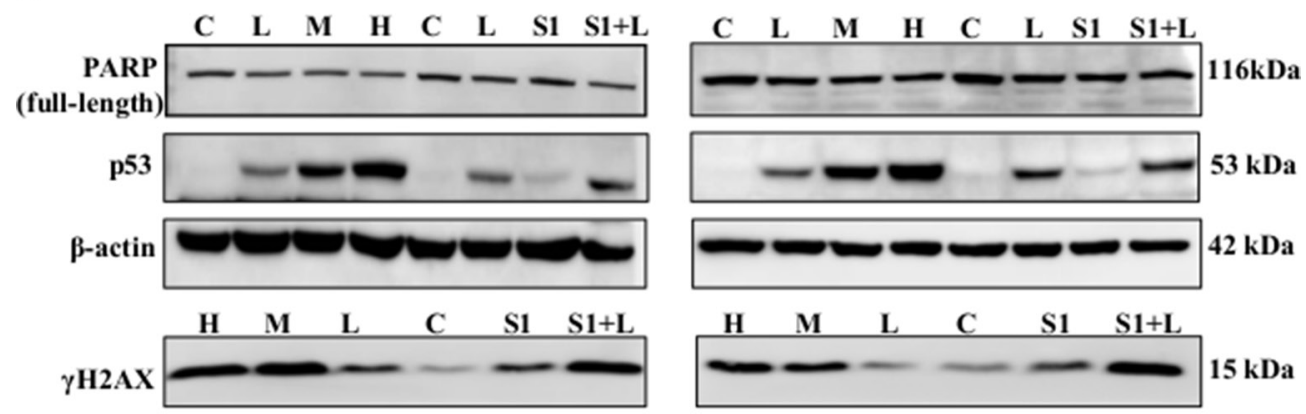

C
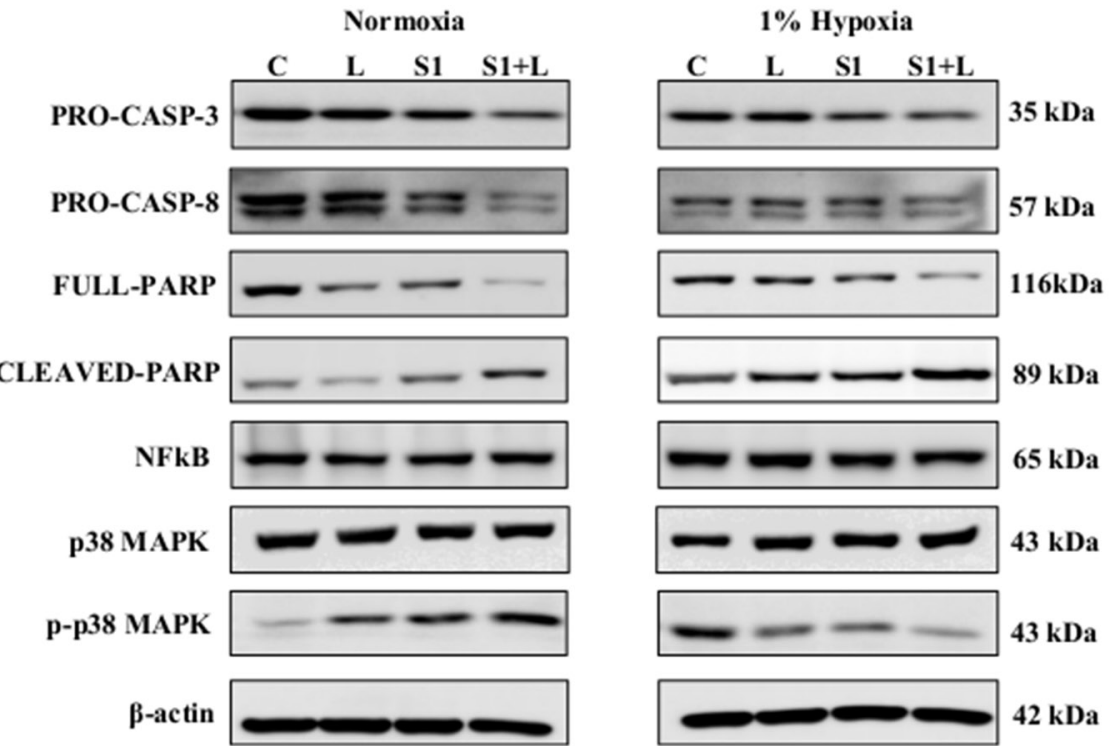

Figure 4: Molecular analysis of cell death and cell signaling markers. (A) AnnexinV-PI dual staining and flow cytometry analysis of lung cancer cells showed elevated levels of apoptotic cell death in combination treatment in normoxia as well as hypoxia. (B) Western blot analysis for DNA damage and cell death markers shows a synergistic improvement in combination treatment compared to low dose single agent treatment. (C) Western blot analysis shows the activation of caspase-mediated apoptosis in response to combination treatment in both normoxic and hypoxic conditions. Q1=necrotic population, Q2=late phase apoptosis, Q3=live cells, Q4= early phase apoptosis. $\mathrm{C}=$ control, $\mathrm{L}=2 \mu \mathrm{g} / \mathrm{ml}$ cisplatin $\mathrm{M}=5 \mu \mathrm{g} / \mathrm{ml}$ cisplatin, $\mathrm{S} 1=1 \mu \mathrm{g} / \mathrm{ml}$ scriptaid. 
cells in vitro, by using a combination of low dose cisplatin and scriptaid.

We have noted dose-dependent cytotoxicity of cisplatin and scriptaid on two lung cancer cell lines- A549 and H460. Both cells lines showed resistance to cisplatin in the two grades of hypoxia studied, albeit at variable doses. Thus, the heterogeneity of tumor hypoxia elicits varied responses depending on the cells of origin. Similar to other reports $[33,34]$, cisplatin induced an $\mathrm{S} / \mathrm{G}_{2}-\mathrm{M}$ phase arrest coupled with reduced $\mathrm{G}_{0}-\mathrm{G}_{1}$ cell population. In hypoxic conditions, however, lung cancer cells overcame S/G2-M phase arrest along with an increase in G0-G1 population, a characteristic feature of hypoxia [35].

HDAC inhibitors such as TSA (trichostatin A) and

A

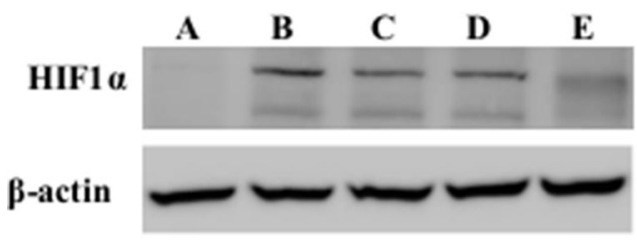

$116 \mathrm{kDa}$

B

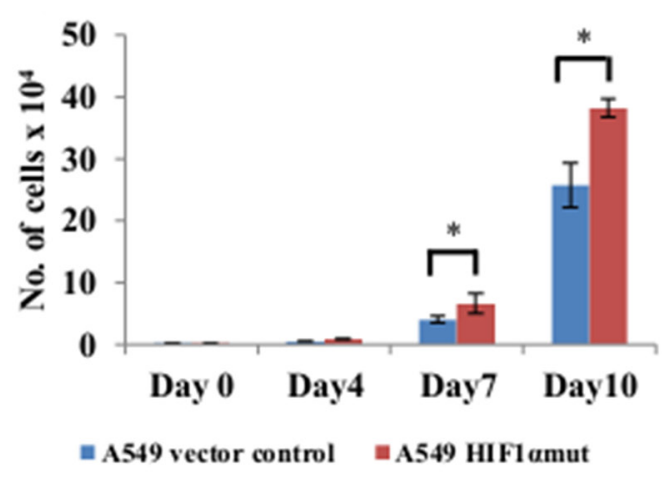

D

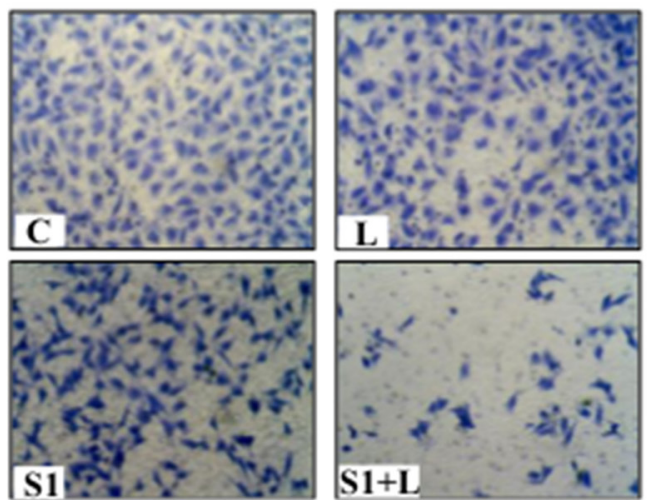

panobinostat have shown potential in overcoming drug resistance in cancer therapy $[36,37]$. While the use of HDAC inhibitors such as TSA and SAHA (suberoylanilide hydroxamic acid) in cancer therapy has been well studied, investigations on Scriptaid- a novel pan-HDAC inhibitor- are less reported. We selected sub-lethal doses of cisplatin and scriptaid for combination treatment to mimic conditions likely to occur in hypoxic tumor interiors. In all three conditions- Normoxia, $1 \%$ hypoxia and $0.2 \%$ hypoxia- the combination proved to be significantly more effective than monotherapy. The synergistic effect of combination was calculated by the method described by Kern et al. [38]. The combination was particularly more effective in hypoxic conditions and led to more cell death
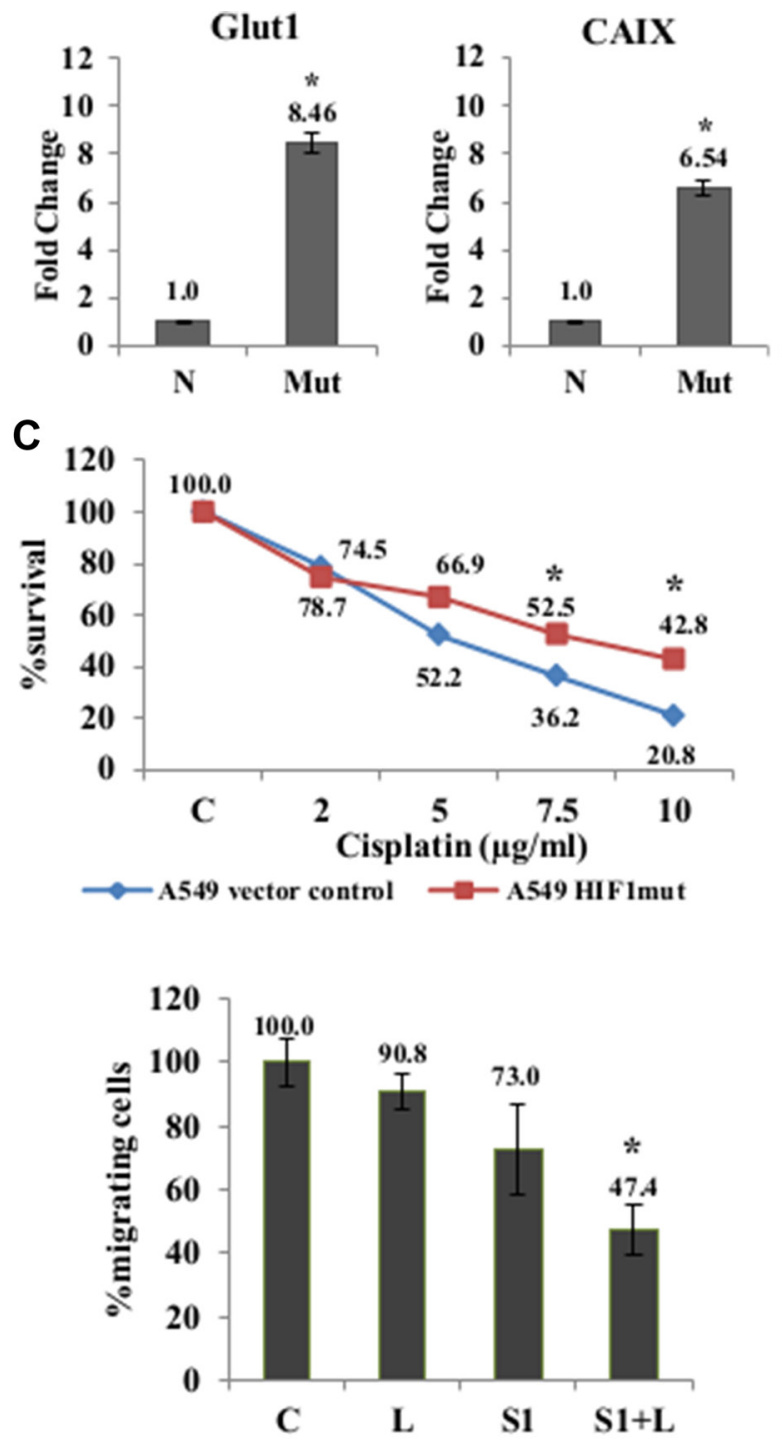

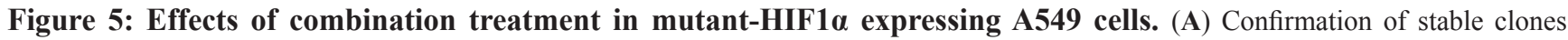
was done by western blot analysis using HIF1 $\alpha$ specific antibody. Clone B was selected for further experiments. qRT-PCR showed an up-regulation of of HIF1-inducible genes (Glut1 and CAIX) in A549/HIF1 $\alpha$ mut cells. The A549/HIF1 $\alpha$ mut cells showed a higher rate of proliferation (B) and resistance to cisplatin (C) compared to A549 cells with wt-HIF1 $\alpha$. (D) Migration assay using Boyden chambers showed a significant inhibition of migration in A549/HIF1mut cells in response to combination treatment than that seen in monotherapy. $\mathrm{A}=$ empty vector control; $\mathrm{B}, \mathrm{C}, \mathrm{D}, \mathrm{E}=$ different selected clones. $\mathrm{C}=$ control, $\mathrm{L}=2 \mu \mathrm{g} / \mathrm{ml}$ cisplatin, $\mathrm{S} 1=1 \mu \mathrm{g} / \mathrm{ml}$ scriptaid. * indicates $p<0.05$. 
than single agent cisplatin. Low doses of either cisplatin or scriptaid did not lead to significant DNA damage as a single agent, while the combination elicits high levels of DNA damage in both normoxia and hypoxia as observed by morphology and flow cytometry analysis using annexinV/PI dual staining.

Cisplatin is known to induce p53 and lead to the activation of mitochondrial apoptosis pathway [39]. We observed enhanced p53 activation with increasing dose of cisplatin. p53 expression in combination treatment was not similar to high dose cisplatin. Thus, augmentation of apoptosis upon doublet treatment may also involve other pathways apart from the p53-induced apoptosis. Cleavage of pro-caspase 3 and pro-caspase 8 indicates that the extrinsic pathway of apoptosis is active in doublet treated samples. Our results indicate that p-p38MAPK plays

\section{A}

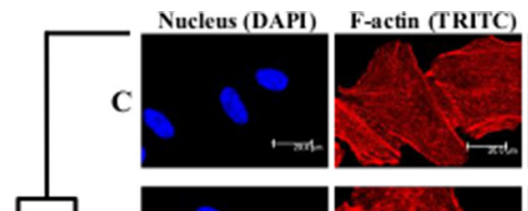

$\because-\mathrm{H} 2 \mathrm{AX}(\mathrm{FITC})$

MERGE
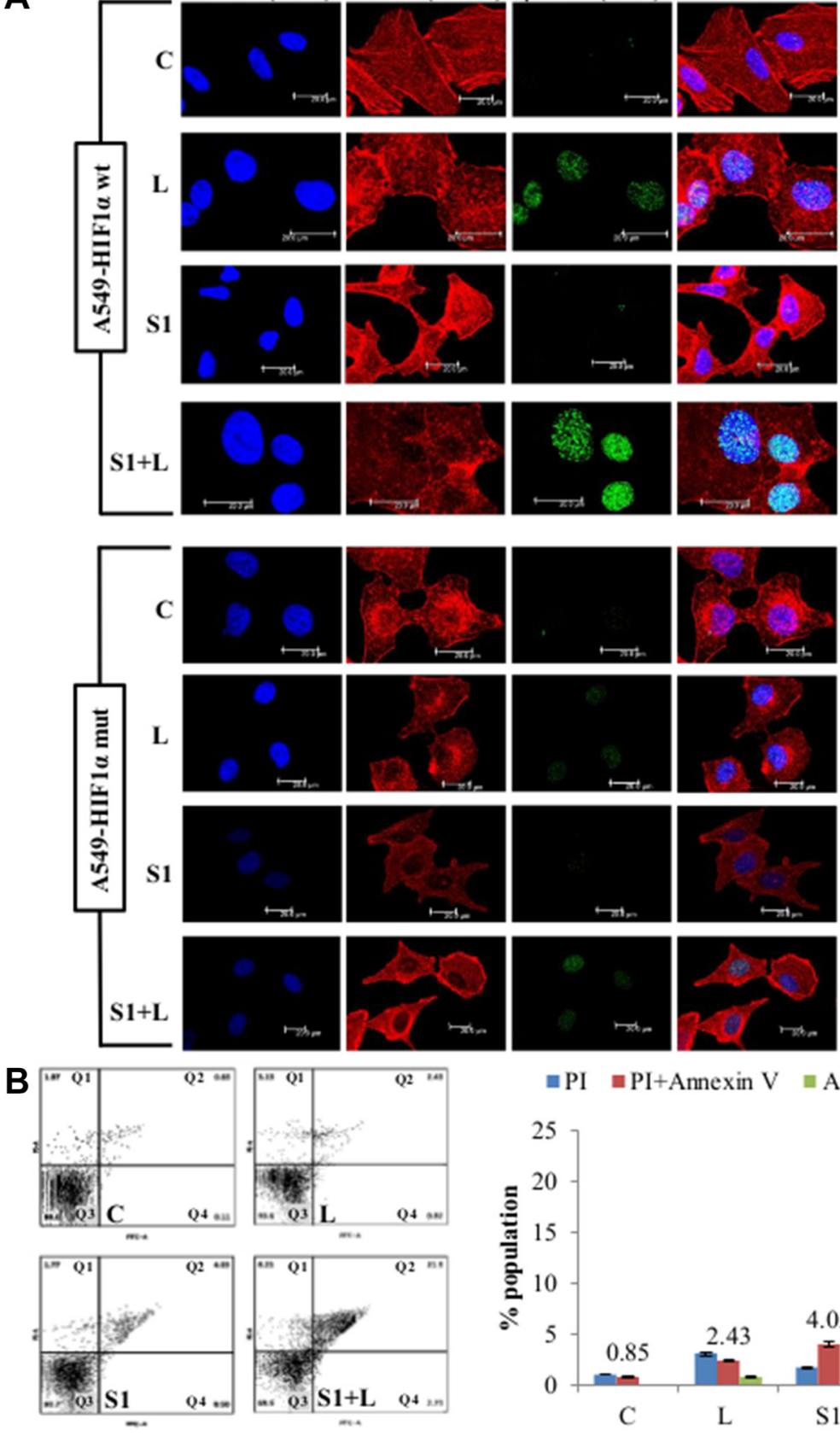

=PI $=\mathrm{PI}+$ Annexin $\mathrm{V}=$ Annexin $\mathrm{V}$

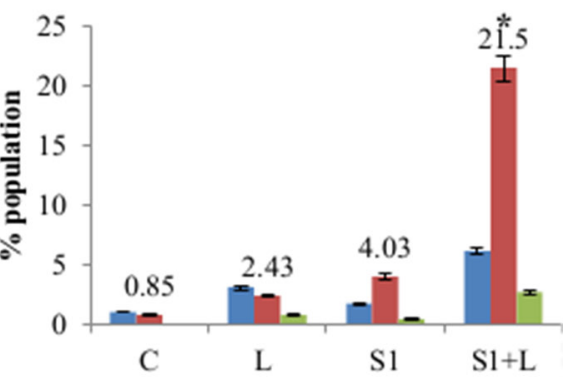

Figure 6: Cell death and DNA damage in response to treatment in A549/HIF1 $\alpha$ mut cells. (A) Confocal images of A549/wtHIF $1 \alpha$ and A549/HIF $1 \alpha$ mut shows an elevated level of DNA damage in combination than single agent treatment. Increased accumulation of $\gamma$-H2AX indicates DNA damage. Nucleus= Blue (DAPI), F-actin= Red (TRITC), $\gamma$-H2AX= Green (FITC). (B) AnnexinV-PI dual staining and flow cytometry analysis shows significantly higher apoptosis in combination treatment than low dose cisplatin and scriptaid. $\mathrm{Q} 1=$ necrotic population, Q2=late phase apoptosis, Q3=live cells, Q4= early phase apoptosis. C= control, L=2 $\mu \mathrm{g} / \mathrm{ml} \mathrm{cisplatin,} \mathrm{S} 1=1 \mu \mathrm{g} / \mathrm{ml}$ scriptaid. * indicates $p<0.05$. 
different roles in survival and cell death in response to the micro-environment. p38MAPK has shown variable characteristic in many studies, of promoting cell death $[40,41]$ and enhancing survival, depending on the conditions and cell-type [42]. Expression of p-p38MAPK appears to play an important role in apoptosis in normoxic condition, while it may provide cell survival signals in hypoxic micro-environment. NFкB is a major downstream effector of hypoxia response [43, 44] and an important player in the immune response to cancer. While, NFkB expression was elevated in hypoxia, its expression remained unaffected in response to treatment in both conditions. Tumor hypoxia has been shown to be associated with necrotic cell death [45] and we observed
A

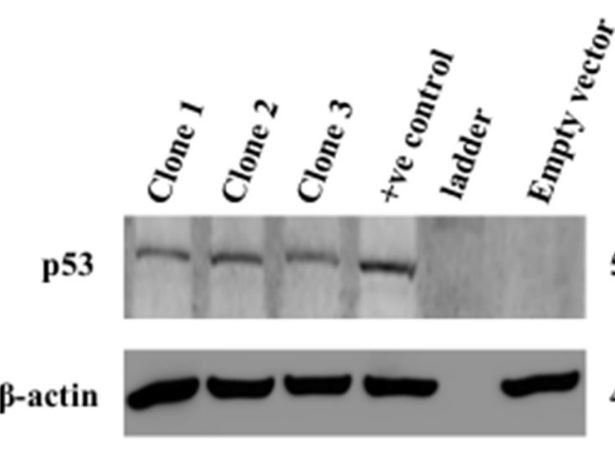

$53 \mathrm{kDa}$

$42 \mathrm{kDa}$

C
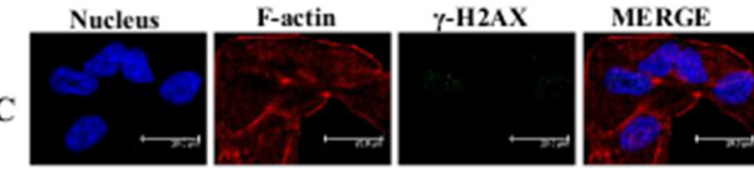

$\mathbf{L}$
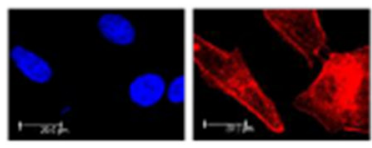

S1
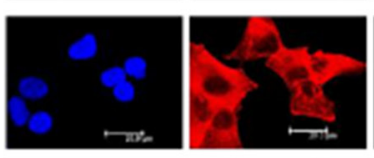

$\mathbf{S} 1+\mathbf{L}$
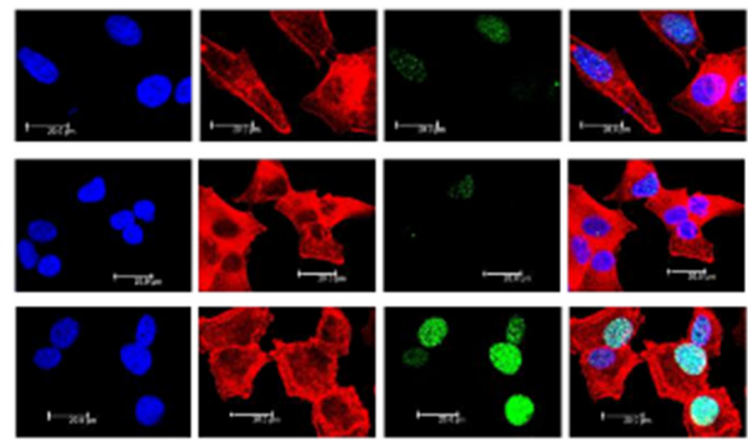

E
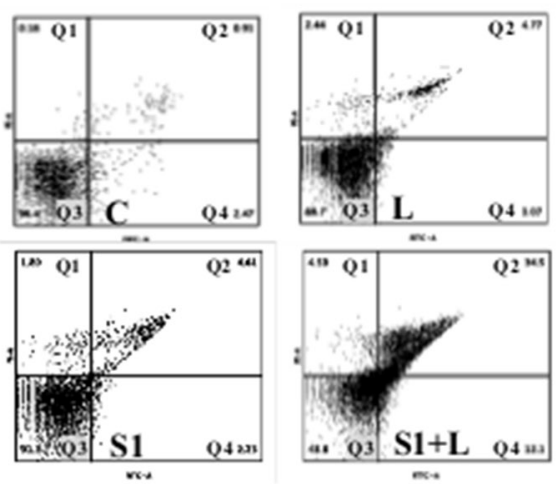

B
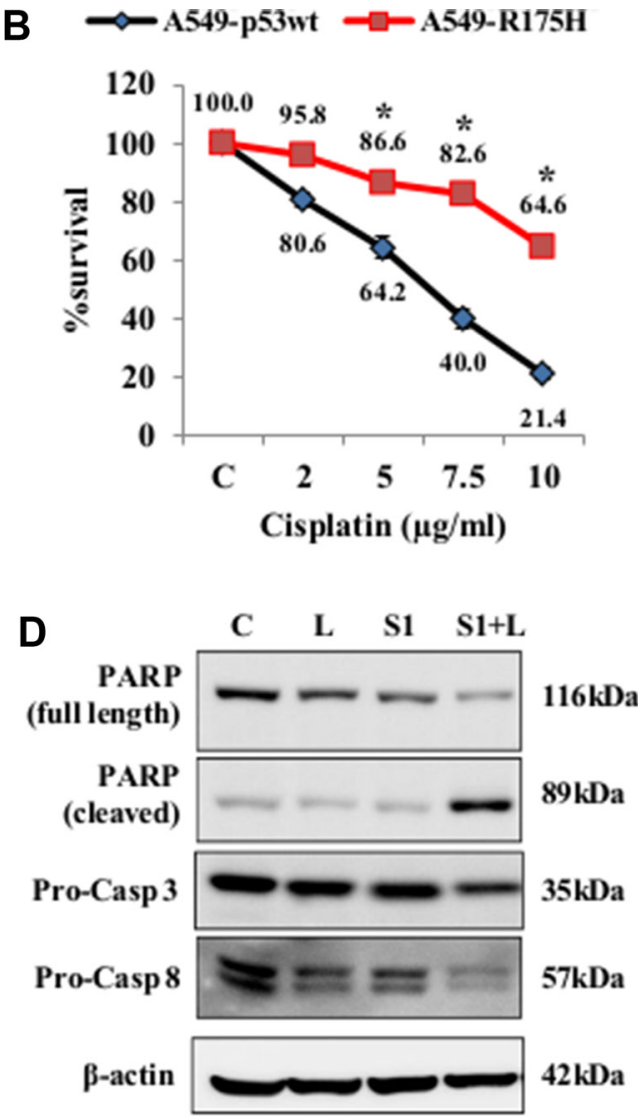

Figure 7: Cell death and DNA damage in response to treatment in A549/p53 dominant-negative cells. (A) Confirmation of stable clones was done by western blot analysis using p53 specific antibody. (B) MTT assay for cisplatin shows that the mutant cell line is resistant to the drug as compared p54-wt A549 cells. (C) Confocal images of A549/p53 dominant negative cells shows an elevated level of DNA damage in combination than single agent treatment. Increased accumulation of $\gamma-\mathrm{H} 2 \mathrm{AX}$ indicates DNA damage. Nucleus= Blue (DAPI), F-actin= Red (TRITC), $\gamma$-H2AX= Green (FITC). (D) Western blot analysis shows a caspase mediated cell death in A549/ p53 mut cells in response to treatment. (E) AnnexinV-PI dual staining and flow cytometry analysis shows significantly higher apoptosis in combination treatment than low dose cisplatin and scriptaid. Q1=necrotic population, Q2=late phase apoptosis, Q3=live cells, Q4= early phase apoptosis. $\mathrm{C}=$ control, $\mathrm{L}=2 \mu \mathrm{g} / \mathrm{ml}$ cisplatin, $\mathrm{S} 1=1 \mu \mathrm{g} / \mathrm{ml}$ scriptaid. * indicates $p<0.05$. 
marginal necrosis in cells exposed to hypoxia. That the combination treatment proved to be more toxic and resulted in higher apoptosis than single agent cisplatin or scriptaid, even in hypoxia, is an extremely relevant and significant finding. Single agent treatment retards cell migration and the combination furthers inhibits migratory properties of cancer cells as observed by functional studies and molecular analysis of EMT markers.

To determine whether HIF $1 \alpha$ is the major effector molecule of our observations on cisplatin-resistance in hypoxia, we generated stable A549 cells expressing a mutant form of HIF1 $\alpha$, which is stabilized under normoxia, while maintaining the wild-type functions. A549/ HIF $1 \alpha$ mut cells were significantly more proliferative than cells with wild-type HIF $1 \alpha$. Over-expression of HIF $1 \alpha$ has been associated with enhanced cell migration of cancer cell [46, 47]. The A549/HIF1 $\alpha$ mut cells were highly migratory, and similar to cells exposed to hypoxia, responded weakly to single agent treatment. The combination treatment significantly enhanced DNA damage and apoptotic cell death in A549/HIF1 $\alpha$ mut cells apart from inhibiting cell migration. Thus, we conclude that cisplatin-resistance of lung cancer cells in hypoxic micro-environment is mostly regulated by HIF $1 \alpha$ and the combination therapy overcomes this resistance.

In order to address the role of major genetic mutation in NSCLC, we generated a dominant negative p53 expressing stable A549 cells- A549-R175H p53 mutant, to determine the effectiveness of the combination therapy in this genetic background. p53 mutation is a common phenomenon in lung cancer and linked to decreased survival in patients receiving cisplatinbased chemotherapy [48], TP53 mutational spectrum in human cancers has shown the $\mathrm{R} 175 \mathrm{H}$ mutation occurs most frequently with an overall frequency of 4.6\% [49]. The A549-R175H cells were significantly resistant to all doses of cisplatin compared to A549 cells with wtp53. Immunostaining with $\gamma-\mathrm{H} 2 \mathrm{AX}$ showed that single agent cisplatin and scriptaid did not result in significant DNA damage in A549/R175H cells. The combination therapy, however, led to synergistic enhancement in DNA damage. Using annexinV/PI dual staining and western blot analysis with cell death markers, we have shown that the combination therapy is effective in a p53-dominant negative genetic background and also overcomes cisplatin resistance in lung cancer cells.

In our study we have determined the effectiveness of low doses scriptaid and cisplatin combination therapy in the heterogeneous tumor microenvironment. Apart from the pre-dominant EGFR and RAS mutations that occur in most NSCLC, significant population of patients acquire p53 (R175H) mutations. The combination dose was, hence, tested for cytotoxicity in vitro on the genotype observed in two main groups of activating mutations found in NSCLC patients, the EGFR-LKB1-RAS (A549 cell line) and EGFR-LKB1-RAS-p53 (A549-R175H p53 mutant cell line), in both normoxia and hypoxia.

Presently, the success rate of drugs from pre-clinical phase to clinical trials remains poor. The combination of low dose cisplatin and scriptaid is equally effective in hypoxia, and possibly, the tumor interiors. The success of the combination in vivo is, however, yet to be tested. We believe that screening drugs by exhaustively addressing the dynamics of the tumor microenvironment at the early stage of pre-clinical trials, will increase the success rates in vivo and eventually, in further trials.

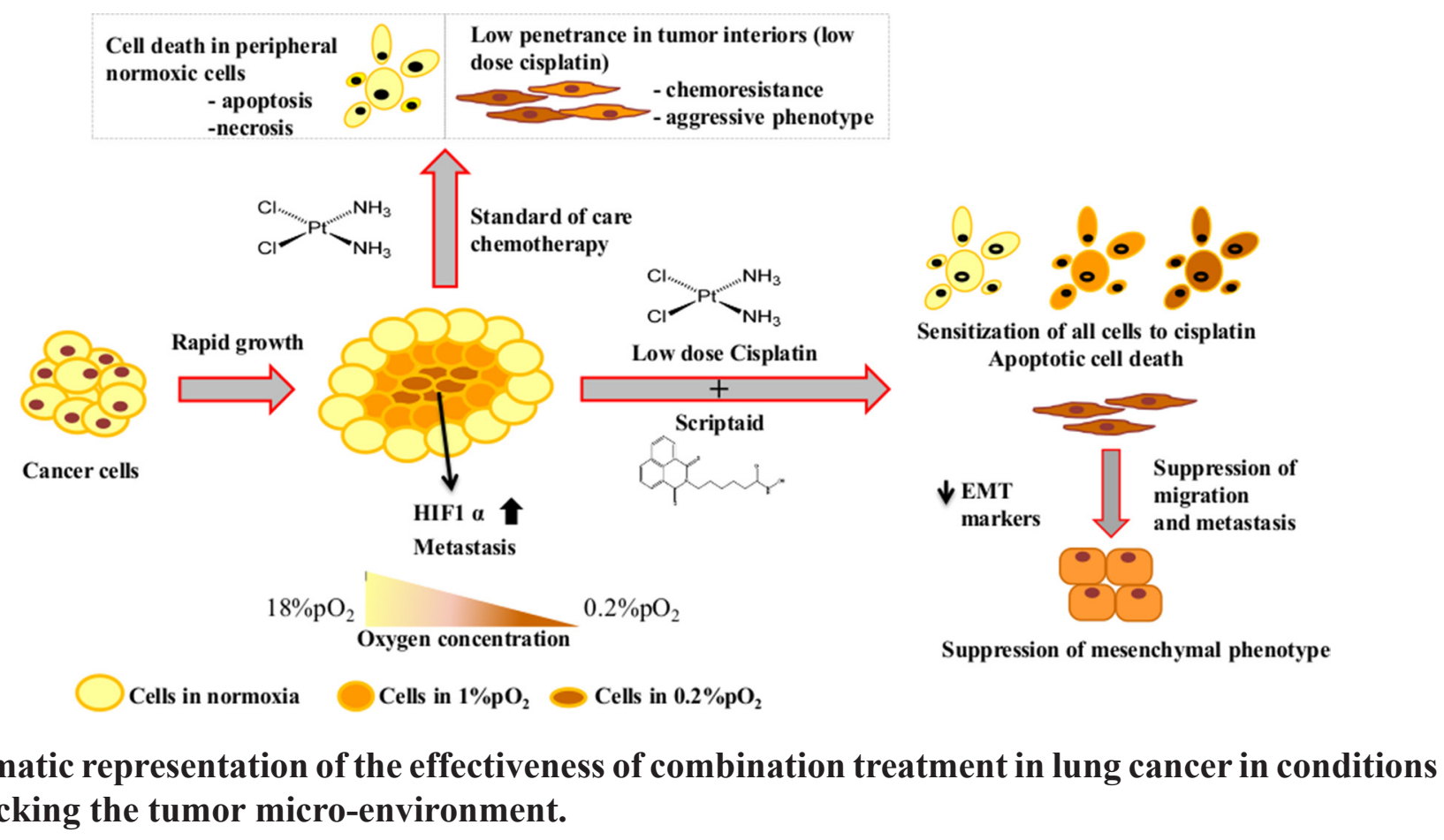




\section{MATERIALS AND METHODS}

\section{Cell lines and cell culture}

The human lung cancer cell lines- A549 (nonsmall cell lung cancer) and H460 (large cell lung cancer) were procured from the National Centre for Cell Science (NCCS), Pune and cultured in Dulbecco's Modified Eagle Medium (DMEM, Gibco, USA), supplemented with $10 \%$ serum (FBS, Gibco, EU approved). Cells were incubated in a humidified incubator with $5 \% \mathrm{CO}_{2}$ at $37^{\circ} \mathrm{C}$. For maintaining in vitro hypoxic conditions, cell culture dishes were incubated in Anoxomat chambers (Mart ${ }^{\mathbb{R}}$ Microbiology and the Anoxomat ${ }^{\mathrm{TM}}$ system) with regulated concentrations of $\mathrm{N}_{2}, \mathrm{CO}_{2}$ and $\mathrm{O}_{2}$. Culture conditions with atmospheric oxygen concentration is referred to as normoxia, whereas culture conditions with $1 \% \mathrm{O}_{2}$ and $0.2 \% \mathrm{O}_{2}$ is referred to as $1 \%$ hypoxia and $0.2 \%$ hypoxia respectively.

\section{Cytotoxicity and viability assays}

MTT assay was performed to determine the toxicity of the drugs on lung cancer cell lines. Cells seeded in 96well plates, at a density of $1 \times 10^{5}$ cells per well, were given the indicated drug treatment-Cisplatin (Sigma, USA) and Scriptaid (Sigma, USA) for $72 \mathrm{hrs.} 100 \mu \mathrm{l}$ of MTT solution $(100 \mu \mathrm{g} / \mathrm{ml})$ was added to each well and after its conversion to a soluble formazan, cell viability was measured by spectrophotometric absorbance at $490 \mathrm{~nm}$. For clonogenic assay, cells were seeded at a density of 1000 cells per well in 6-well plates coated with poly-Llysine (Sigma, USA). After giving the indicated treatment for $2 \mathrm{hrs,} \mathrm{cells} \mathrm{were} \mathrm{grown} \mathrm{in} \mathrm{regular} \mathrm{growth} \mathrm{media} \mathrm{for}$ 2 weeks. The resulting colonies were fixed, stained with $0.5 \%$ crystal violet and counted using the ImageJ image analysis software.

\section{Wound healing and migration assay}

For wound heal (scratch) assay, $1 \times 10^{5}$ cells per well were seeded to form a monolayer of cells in 24 well plates. A single wound was made in each well using a pipette tip and the indicated treatment given. Images were captured at time 0 and $24 \mathrm{hrs}$ after wound infliction to determine the amount of cell migration. ImageJ software was used to calculate percent migration. In migration assay, cells were seeded at a density of $1 \times 10^{5}$ in transwell inserts in serum-free media. $800 \mu \mathrm{l}$ of serum-containing media was added in each well and inserts placed on top of each well. Indicated treatments were then given to each well and the plates incubated for $24 \mathrm{hrs}$. Cells trapped in the membrane of the insert by virtue of the FBS gradient were fixed and stained with Giemsa stain. The images were captured at a magnification of $20 \times$ and number of cells counted using the ImageJ image analysis software.

\section{Cell cycle analysis}

Cells seeded in cell culture dishes were given indicated treatments for $48 \mathrm{hrs}$. The cells were then harvested followed by an overnight fixation in $70 \%$ ethanol at $-20^{\circ} \mathrm{C}$. Cells were washed with PBS to remove any trace of ethanol and RNase (Invitrogen, USA) was added to remove RNA from the samples. $40 \mu \mathrm{g}$ of propidium iodide (Sigma, USA) was then added to each sample and acquired with BD-FACS Calibur. The data so obtained were analyzed by WinMDI software (Version 2.9).

\section{AnnexinV/PI staining analysis}

AnnexinV FITC/PI dual staining is performed to differentiate between apoptotic and necrotic cell death. Cells seeded in cell culture dishes were given the indicated treatments for $48 \mathrm{hrs}$. The cells were then harvested and suspended in cold PBS. The dual staining using FITCAnnexinV and PI was done using manufacturer's protocol (\#V13242, Invitrogen, USA). The samples were analyzed by flow cytometry, measuring the fluorescence emission at $530 \mathrm{~nm}$ and $>575 \mathrm{~nm}$. Flow cytometry analysis was done BD FACS Verse and the experiment performed in three biological replicates. FlowJo software was used for data analysis.

\section{Plasmid vectors}

Two recombinant plasmid vectors were used in the study. The HIF $1 \alpha$ mutant coding plasmid- HA-HIF 1alpha P402A/P564A-pcDNA3 was gifted by William Kaelin [29] (\#18955). The expressed protein has a mutation at amino acid position 402 and 564, which prevents its degradation under normoxic conditions and retains its function. The p53-dominant negative expressing plasmidpCMV-Neo-Bam-R175H was gifted by Bert Vogelstein [30] (\#16436). The mutant p53 protein has a mutation at amino acid position 175 . This dominant negative protein dimerizes with the wild-type p53 and prevents its normal functioning.

\section{Immunofluorescence and confocal microscopy}

Cells were cultured in chamber slides and given the indicated treatments. Cells were fixed with $4 \%$ paraformaldehyde washed twice with cold PBS and then permeabilized with $0.2 \%$ Triton X-100 for 5 mins at room temperature. For immunostaining, cells were incubated with rabbit-anti- $\gamma \mathrm{H} 2 \mathrm{AX}$ antibody in recommended dilution overnight at $4^{\circ} \mathrm{C}$. Alexa Fluor ${ }^{\circledR} 488$ (Invitrogen, USA) (1:100), prepared in 1\% BSA, was added to each well of the chamber slide and incubated for $1 \mathrm{hr}$. Actin fibers were stained with phalloidin (Cytoskeleton, USA) and nuclei were stained with 4,6-diamidino-2phenylindole (DAPI) (Sigma, USA). Fluorescent images 
at the respective wavelengths were first captured on an inverted fluorescence microscope (Olympus IX83, Japan). For high resolution images, confocal images were captured at 60X magnification of the objective (Leica TCS SP5). Image analysis of confocal images was performed using the LAS AF Lite software. CTCF was calculated using ImageJ software.

\section{RNA isolation and real-time PCR}

Cells cultured in petri dishes were given indicated treatments in respective conditions for $24 \mathrm{hrs}$. RNA was isolated using Trizol (Sigma, USA). Total RNA, eluted in $40 \mu \mathrm{l}$ of nuclease free water, was quantified using Nanodrop (Thermo Scientific, USA). $1 \mu \mathrm{g}$ of total RNA was used for preparing $20 \mu \mathrm{l}$ of cDNA according to manufacturer's protocol (Revert Aid cDNA synthesis, \#K1621). All primers for real-time PCR were prepared using the Primer3 online tool. Real-time PCR was performed in Rotor-Gene Q (Qiagen) by using FIREPol EvaGreen (Solis Biodyne, \#08-24-00001) master mix. $\beta$-2-microglobulin (B2M) was used as the internal control. Each experiment was performed in three replicates.

\section{Western blotting}

Cells were washed with cold PBS and the cells harvested in $1 \times$ lysis buffer. Protein estimation was performed using Bradford assay according to manufacturer's protocol (Biorad, USA \#500-0201). $40 \mu \mathrm{g}$ of each lysate was separated by SDS-PAGE and transferred onto PVDF membrane (MDI, India). The proteins in the membrane were probed with specific antibodies and detected by chemiluminescence (Thermo Scientific, USA).

\section{Statistical analysis}

All in vitro experiments were performed at least in three biological replicates for reproducibility of data. Each data point represents at least three technical replicates. Bars in the graph represent standard deviation. Student's $t$-test was used for comparing the difference between two groups and $p<0.05$ was considered as statistically significant.

\section{Antibodies used}

PARP- full length (\#9542), PARP- cleaved (\#9541), p53 (\#9282), $\gamma$-H2AX (\#9718), caspase 8 (\#9746S), p38MAPK (\#9212) and p-p38MAPK (\#9211) antibodies were procured from Cell Signaling Technology, USA. Anti-histone H4 (acetylated) (\#ab51997) and caspase 3 (\#ab32351) antibodies were procured from Abcam, UK.

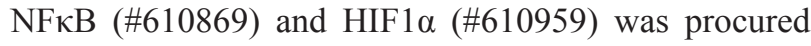
from BD Biosciences, USA and $\beta$-actin (\#NB600-501) from Novus Biologicals, USA.

\section{ACKNOWLEDGMENTS}

SP and DM are recipients of Senior Research Fellowship from Council of Scientific and Industrial Research. PK is a recipient of Senior Research Fellowship from University Grant Commission. NP is a recipient of UGC-SAP (special assistance program) Meritorious Award from Delhi University. CS is supported by Innovation Award from Centre for Bio-design and Diagnostics. We thank Ms. Shabana and Mr. Krishna Gopal for technical help.

\section{CONFLICTS OF INTEREST}

The authors have no conflicting interest to declare.

\section{GRANT SUPPORT}

This work was funded by research grant from Department of Science and Technology (DST), Department of Biotechnology (DBT) and university R\&D to TS. We also thank UGS for SAP (BRS III), DST for FIST (level II) program and DU- DST PURSE (phaseII) for supporting our work.

\section{REFERENCES}

1. Webb JD, Simon MC. Novel insights into the molecular origins and treatment of lung cancer. Cell Cycle. 2010; 9:4098-4105.

2. Brambilla E, Travis WD, Colby TV, Corrin B, Shimosato Y. The new World Health Organization classification of lung tumours. Eur Respir J. 2001; 18:1059-1068.

3. Viktorsson K, De Petris L, Lewensohn R. The role of p53 in treatment responses of lung cancer. Biochem Biophys Res Commun. 2005; 331:868-880.

4. El-Sherif A, Luketich JD, Landreneau RJ, Fernando HC. New therapeutic approaches for early stage non-small cell lung cancer. Surg Oncol. 2005; 14:27-32.

5. Kelland L. The resurgence of platinum-based cancer chemotherapy. Nat Rev Cancer. 2007; 7:573-584.

6. Dasari S, Bernard Tchounwou P. Cisplatin in cancer therapy: Molecular mechanisms of action. European journal of pharmacology. 2014; 740:364-378.

7. Galluzzi L, Senovilla L, Vitale I, Michels J, Martins I, Kepp O, Castedo M, Kroemer G. Molecular mechanisms of cisplatin resistance. Oncogene. 2012; 31:1869-1883.

8. Liao D, Johnson RS. Hypoxia: a key regulator of angiogenesis in cancer. Cancer Metastasis Rev. 2007; 26:281-290.

9. Srivastava T, Seth A, Datta K, Chosdol K, Chattopadhyay P, Sinha S. Inter-alu PCR detects high frequency of genetic alterations in glioma cells exposed to sub-lethal cisplatin. Int J Cancer. 2005; 117:683-689. 
10. Semenza GL, Roth PH, Fang HM, Wang GL. Transcriptional Regulation of Genes Encoding Glycolytic Enzymes by Hypoxia-inducible Factor 1. The Journal of biological chemistry. 1994; 269, 23757-23763.

11. Liao D, Corle C, Seagroves TN, Johnson RS. Hypoxiainducible factor- $1 \alpha$ is a key regulator of metastasis in a transgenic model of cancer initiation and progression. Cancer Res. 2007; 67:563-572.

12. Mazumdar J, Hickey MM, Pant DK, Durham AC, SweetCordero A, Vachani A, Jacks T, Chodosh LA, Kissil JL, Simon MC, Keith B. HIF-2 $\alpha$ deletion promotes Kras-driven lung tumor development. Proc Natl Acad Sci USA. 2010; 107:14182-14187.

13. Maranchie JK, Vasselli JR, Riss J, Bonifacino JS, Linehan WM, Klausner RD. The contribution of VHL substrate binding and HIF 1- $\alpha$ to the phenotype of VHL loss in renal cell carcinoma. Cancer cell. 2002; 1:247-255.

14. Raval RR, Lau KW, Tran MG, Sowter HM, Mandriota SJ, Li JL, Pugh CW, Maxwell PH, Harris AL, Ratcliffe PJ. Contrasting properties of hypoxia-inducible factor 1 (HIF-1) and HIF-2 in von Hippel-Lindau-associated renal cell carcinoma. Mol Cell Biol. 2005; 25:5675-5686.

15. Miller VA, $\mathrm{Ng} \mathrm{KK}$, Grant SC, Kindler H, Pizzo B, Heelan RT, von Roemeling R, Kris MG. Phase II study of the combination of the novel bioreductive agent, tirapazamine, with cisplatin in patients with advanced nonsmall-cell lung cancer. Ann Oncol.1997; 8:1269-1271.

16. Maluf FC, Leiser AL, Aghajanian C, Sabbatini P, Pezzulli S, Chi DS, Wolf JK, Levenback C, Loh E, Spriggs DR. Phase II study of tirapazamine plus cisplatin in patients with advanced or recurrent cervical cancer. Int J Gynecol Cancer. 2006; 16:1165-1171.

17. Gatineau M, Rixe O, Chevalier TL. Tirapazamine with cisplatin and vinorelbine in patients with advanced nonsmall-cell lung cancer: a phase I/II study. Clin Lung Cancer. 2005; 6:293-298.

18. Rischin D, Peters L, Fisher R, Macann A, Denham J, Poulsen M, Jackson M, Kenny L, Penniment M, Corry J, Lamb D, McClure B. Tirapazamine, Cisplatin, and Radiation versus Fluorouracil, Cisplatin, and Radiation in patients with locally advanced head and neck cancer: a randomized phase II trial of the Trans-Tasman Radiation Oncology Group (TROG 98.02). J Clin Oncol. 2005; 23:79-87.

19. Shepherd F, Koschel G, von Pawel J, Gatzmeier U, Van Zandwiyk N, Woll P, Van Klavren R, Krasko P, Desimone P, Nicolson M, Pieters W, Bigelow R, Rey A, et al. Comparison of Tirazone (Tirapazamine) and cisplatin vs. etoposide and cisplatin in advanced non-small cell lung cancer (NSCLC): Final results of the international Phase III CATAPULT II Trial. Lung Cancer. 2000; 29:28.

20. Williamson SK, Crowley JJ, Lara PN, Jr., McCoy J, Lau DH, Tucker RW, Mills GM, Gandara DR. Phase III trial of paclitaxel plus carboplatin with or without tirapazamine in advanced non-small-cell lung cancer: Southwest Oncology Group Trial S0003. J Clin Oncol. 2005; 23:9097-9104.

21. Jones PA, Baylin SB. The epigenomics of cancer. Cell. 2007; 128:683-692.

22. Pal A, Srivastava T, Sharma MK, Mehndiratta M, Das P, Sinha S, Chattopadhyay P. Aberrant methylation and associated transcriptional mobilization of Alu elements contributes to genomic instability in hypoxia. J Cell Mol Med. 2010; 14:2646-2654.

23. Ueda J, Ho JC, Lee KL, Kitajima S, Yang H, Sun W, Fukuhara N, Zaiden N, Chan SL, Tachibana M, Shinkai Y, Kato H, Poellinger L. The hypoxia-inducible epigenetic regulators Jmjd1a and G9a provide a mechanistic link between angiogenesis and tumor growth. Mol Cell Biol. 2014; 34:3702-3720.

24. Chen H, Yan Y, Davidson TL, Shinkai Y, Costa M. Hypoxic Stress Induces Dimethylated Histone H3 Lysine 9 through Histone Methyltransferase G9a in Mammalian Cells. Cancer Research. 2006; 66:9009-9016.

25. Baxter E, Windloch K, Gannon F, Lee JS. Epigenetic regulation in cancer progression. Cell Biosci. 2014; 4:1.

26. Lee KJ, Lee KY, Lee YM. Downregulation of a tumor suppressor RECK by hypoxia through recruitment of HDAC1 and HIF-1 $\alpha$ to reverse HRE site in the promoter. Biochim Biophys Acta. 2010; 1803:608-616.

27. Lee JS, Kim Y, Kim IS, Kim B, Choi HJ, Lee JM, Shin HJ, Kim JH, Kim JY, Seo SB, Lee H, Binda O, Gozani O, et al. Negative regulation of hypoxic responses via induced Reptin methylation. Mol cell. 2010; 39:71-85.

28. Perez-Perri JI, Acevedo JM, Wappner P. Epigenetics: new questions on the response to hypoxia. Int J Mol Sci. 2011; 12:4705-4721.

29. Yan Q, Bartz S, Mao M, Li L, Kaelin WG, Jr. The hypoxia-inducible factor $2 \alpha \mathrm{N}$-terminal and C-terminal transactivation domains cooperate to promote renal tumorigenesis in vivo. Molecular and cellular biology. 2007; 27:2092-2102.

30. Baker SJ, Markowitz S, Fearon ER, Willson JK, Vogelstein B. Suppression of human colorectal carcinoma cell growth by wild-type p53. Science. 1990; 249:912-915.

31. Horibe S, Matsuda A, Tanahashi T, Inoue J, Kawauchi S, Mizuno S, Ueno M, Takahashi K, Maeda Y, Maegouchi T, Murakami Y, Yumoto R, Nagai J, et al. Cisplatin resistance in human lung cancer cells is linked with dysregulation of cell cycle associated proteins. Life Sci. 2015; 124:31-40.

32. Song X, Liu X, Chi W, Liu Y, Wei L, Wang X, Yu J. Hypoxia-induced resistance to cisplatin and doxorubicin in non-small cell lung cancer is inhibited by silencing of HIF$1 \alpha$ gene. Cancer Chemother Pharmacol. 2006; 58:776-784.

33. Vitale I, Galluzzi L, Castedo M, Kroemer G. Mitotic catastrophe: a mechanism for avoiding genomic instability. Nat Rev Mol Cell Biol. 2011; 12:385-392. 
34. O'Grady S, Finn SP, Cuffe S, Richard DJ, O'Byrne KJ, Barr MP. The role of DNA repair pathways in cisplatin resistant lung cancer. Cancer Treat Rev. 2014; 40:1161-1170.

35. Liang D, Ma Y, Liu J, Trope CG, Holm R, Nesland JM, Suo Z. The hypoxic microenvironment upgrades stem-like properties of ovarian cancer cells. BMC Cancer. 2012; 12:1.

36. Wu J, Hu CP, Gu QH, Li YP, Song M. Trichostatin A sensitizes cisplatin-resistant A549 cells to apoptosis by upregulating death-associated protein kinase. Acta Pharmacol Sin. 2010; 31:93-101.

37. Fischer C, Leithner K, Wohlkoenig C, Quehenberger F, Bertsch A, Olschewski A, Olschewski H, Hrzenjak A. Panobinostat reduces hypoxia-induced cisplatin resistance of non-small cell lung carcinoma cells via HIF-1 $\alpha$ destabilization. Mol cancer. 2015; 14:1.

38. Kern DH, Morgan CR, Hidelbrand-Zanki SU. In vitro pharmacodynamics of $1-\beta$-d-arabinofuranosylcytosine: synergy of antitumor activity with cisdiamminedichloroplatinum(II). Cancer Research. 1998; 48:117-121.

39. Seth R, Yang C, Kaushal V, Shah SV, Kaushal GP. p53dependent caspase-2 activation in mitochondrial release of apoptosis-inducing factor and its role in renal tubular epithelial cell injury. The Journal of biological chemistry. 2005; 280:31230-31239.

40. Sarkar D, Su ZZ, Lebedeva IV, Sauane M, Gopalkrishnan RV, Valerie K, Dent P, Fisher PB. mda-7 (IL-24) Mediates selective apoptosis in human melanoma cells by inducing the coordinated overexpression of the GADD family of genes by means of p38 MAPK. Proc Natl Acad Sci USA. 2002; 99:10054-10059.

41. Porras A, Zuluaga S, Black E, Valladares A, Alvarez AM, Ambrosino C, Benito M, Nebreda AR. p38 $\alpha$ mitogenactivated protein kinase sensitizes cells to apoptosis induced by different stimuli. Mol Biol Cell. 2004; 15:922-933.
42. Wada T, Penninger JM. Mitogen-activated protein kinases in apoptosis regulation. Oncogene. 2004; 23:2838-2849.

43. Crisostomo PR, Wang Y, Markel TA, Wang M, Lahm T, Meldrum DR. Human mesenchymal stem cells stimulated by TNF- $\alpha$, LPS, or hypoxia produce growth factors by an NFкB- but not JNK-dependent mechanism. Am J Physiol Cell Physiol. 2008; 294:C675-682.

44. Royds JA, Dower SK, Qwarnstrom EE, Lewis CE. Response of tumour cells to hypoxia: role of p53 and NFkB. Mol Pathol. 1998; 51:55.

45. Mashiko R, Takano S, Ishikawa E, Yamamoto T, Nakai K, Matsumura A. Hypoxia-inducible factor $1 \alpha$ expression is a prognostic biomarker in patients with astrocytic tumors associated with necrosis on MR image. J Neurooncol. 2011; 102:43-50.

46. Chen J, Imanaka N, Chen J, Griffin JD. Hypoxia potentiates Notch signaling in breast cancer leading to decreased E-cadherin expression and increased cell migration and invasion. Br J Cancer. 2010; 102:351-360.

47. Zhao X-Y, Chen T-T, Xia L, Guo M, Xu Y, Yue F, Jiang Y, Chen G-Q, Zhao K-W. Hypoxia inducible factor-1 mediates expression of galectin-1: the potential role in migration/ invasion of colorectal cancer cells. Carcinogenesis. 2010; 31:1367-1375.

48. I Goldstein, V Marcel, M Olivier, M Oren and Hainaut VRaP. Understanding wild-type and mutant p53 activities in human cancer: new landmarks on the way to targeted therapies. Cancer gene therapy. 2011; 18:2-11.

49. Freed-Pastor WA, Prives C. Mutant p53: one name, many proteins. Genes Dev. 2012; 26:1268-1286. 